\title{
Alpha-amino nitrogen in cerebrospinal fluid and its alterations in meningitis, multiple sclerosis, and some other neurological disorders
}

\author{
E. M. WILliamS AND D. M. MATTHEWS ${ }^{1}$ \\ From the Department of Chemical Pathology, Institute of Neurology, \\ The National Hospital, Queen Square, London
}

SYNOPSIS The concentration of alpha-amino nitrogen (a measure of total amino-acids) was estimated in 58 samples of cerebrospinal fluid in which other findings were normal. Values for lumbar and ventricular cerebrospinal fluid in adults, and lumbar cerebrospinal fluid in children, are reported. A relationship was found between the concentrations of alpha-amino nitrogen in lumbar cerebrospinal fluid and in plasma.

Alpha-amino nitrogen was also estimated in 79 samples of fluid from patients with meningitis, cerebral tumour, multiple sclerosis, and other neurological disorders. High concentrations were found in meningitis, spinal block, and xanthochromic fluids. In cerebral tumours, the concentrations were mostly normal. Low concentrations were found in children, in many cases of multiple sclerosis, and in benign intracranial hypertension. In some cases, the changes cannot yet be explained.

Mestrezat (1912) reported that the amino-acid nitrogen level of cerebrospinal fluid was raised in a case of meningitis. Since this time, there have been many investigations of amino-acids in normal and pathological cerebrospinal fluid, but though numerous abnormalities have been reported, results have often been conflicting (e.g., Knauff, 1958; Logothetis and Bovis, 1961; 1962), and no information of useful diagnostic value has been obtained. These disappointing results might have been contributed to by technical difficulties, including the use of non-specific methods for estimating amino nitrogen in the older work, and more recently, the extensive use of the tedious technique of quantitative paper chromatography, which is apt to give different results in the hands of different investigators, and is unsuitable for the detection of minor changes. This paper describes a preliminary survey of the concentrations of alpha-amino nitrogen in cerebrospinal fluid and plasma in control samples and some pathological conditions, using a recently developed and relatively specific colorimetric ninhydrin method. The method does not measure individual amino-acids but gives a reliable estimate of the total amino-acid concentration.

${ }^{1}$ Present address: Department of Chemical Pathology, Vincent Square Laboratories of the Westminster Medical School.

Received for publication 21 June 1965.

\section{MATERIALS AND METHODS}

Samples of cerebrospinal fluid (C.S.F.) were obtained from patients in the following groups: (1) controls: in these, who were undergoing investigation for neurological or psychiatric disorders, the cerebrospinal fluid was normal with respect to total protein, cell count, Pandy, Nonne-Apelt, and Lange tests; (2) cases of meningitis; (3) cases of intracranial tumour; (4) cases of multiple sclerosis; (5) a miscellaneous group of other neurological disorders, details of which are given below.

Cerebrospinal fluid was centrifuged and the supernatant taken for analysis. Heparinized blood samples were drawn at least four hours after the last meal, and the plasma analysed. Samples were stored deep-frozen until analysis. Analyses for alpha-amino nitrogen $\left(\alpha-\mathrm{NH}_{2} \mathrm{~N}\right)$ were made by the colorimetric ninhydrin method (Matthews, Muir, and Baron, 1964; Williams, Donaldson and, Matthews, 1965). In calculating the concentrations of $\alpha-\mathrm{NH}_{2} \mathbf{N}$ in cerebrospinal fluid, water, and plasma water, it was assumed that the water content of normal cerebrospinal fluid was $985 \mathrm{~g}$./1. (Levinson, 1929) and the water content of plasma was calculated from the formula of Eisenman, Mackenzie, and Peters (1936), assuming a protein concentration of $7 \mathrm{~g} . / 100 \mathrm{ml}$. In a few cases, two-dimensional paper chromatography of aminoacids was carried out in butanol-acetic and phenolammonia solvents after deproteinization with 9 volumes of hot ethanol, a volume equivalent to $0.25 \mathrm{ml}$. Cerebrospinal fluid was applied to the paper. No attempt was made at quantitative estimation of the individual amino- 
acids. The significance of differences between means was assessed by the $t$ test.

\section{RESULTS}

The concentrations of $\alpha-\mathrm{NH}_{2} \mathrm{~N}$ in control samples and in the majority of the pathological conditions studied are summarized in Table 1.

CONTROLS The mean $\alpha-\mathrm{NH}_{2} \mathrm{~N}$ in lumbar cerebrospinal fluid from adults aged 16-75 (mean age 46) was $1.23 \mathrm{mg} . / 100 \mathrm{ml}$, and that in ventricular cerebrospinal fluid from adults aged 17-62 (mean age 37) was $1.13 \mathrm{mg} . / 100 \mathrm{ml}$; t the difference was significant $(P<0.05)$. The mean value in lumbar cerebrospinal fluid from children under 5 (1.09 mg./100 ml.) was lower than that in adults $(P<0.01)$. There was no relationship between $\alpha-\mathrm{NH}_{2} \mathrm{~N}$ and age within the adult group. In 14 cases, $\alpha-\mathrm{NH}_{2} \mathrm{~N}$ was estimated in lumbar cerebrospinal fluid (mean $1.21 \mathrm{mg} . / 100 \mathrm{ml}$. or $1.23 \mathrm{mg} . / 100 \mathrm{ml}$. cerebrospinal fluid water) and also in plasma (mean $4.3 \mathrm{mg} . / 100$ $\mathrm{ml}$. or $4.6 \mathrm{mg}$. $/ 100 \mathrm{ml}$. plasma water). The mean ratio of the concentration of $\alpha-\mathrm{NH}_{2} \mathrm{~N}$ in cerebrospinal fluid water to that in plasma water (R) was $0 \cdot 27$. There was a positive correlation between the concentrations of $\alpha-\mathrm{NH}_{2} \mathrm{~N}$ in plasma and cerebrospinal fluid (Fig. 1). There was no relationship between total cerebrospinal fluid protein and the concentration of $\alpha-\mathrm{NH}_{2} \mathrm{~N}$. Chromatography (six samples) showed glutamine, glycine, alanine, valine, leucine, tyrosine, histidine, and small amounts of serine, threonine, and glutamic and aspartic acids, a similar pattern to that reported by Walker, Telles, and Pastore (1955) and Westall (1962).

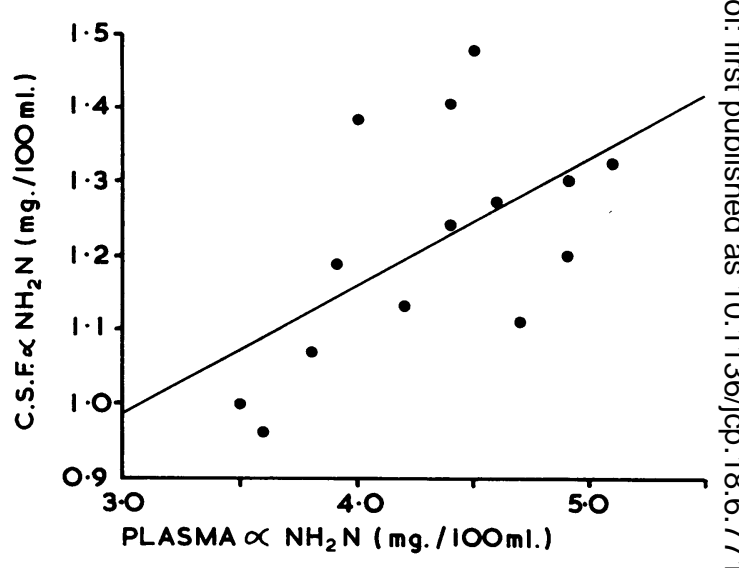

FIG. 1. The relationship between the concentration of $\overrightarrow{\mathrm{O}}$ $\alpha-\mathrm{NH}_{2} \mathrm{~N}$ in plasma and lumbar cerebrospinal fluid. The $\mathrm{J}$ calculated regression line is shown. $(r=0.55$; $P<0.05>0.02$ ).

MENINGITIS In all cases, the values were raised, ranging from 1.9 to $5.4 \mathrm{mg} . / 100 \mathrm{ml}$. There was no correlation between the $\alpha-\mathrm{NH}_{2} \mathrm{~N}$ and total protein $\sigma$ or white cell count. In one case, the cerebrospinal fluid concentration $(5.4 \mathrm{mg} . / 100 \mathrm{ml}$.) substantially exceeded the plasma concentration $(3.7 \mathrm{mg}$. $/ 100 \mathrm{ml}$.). In another, the $\alpha-\mathrm{NH}_{2} \mathrm{~N}$ level was only slightly raised $(1.9 \mathrm{mg} . / 100 \mathrm{ml}$.) while other changes were very gross (total protein $900 \mathrm{mg} . / 100 \mathrm{ml}$., white cell count $10,000 /$ c mm., sugar $5 \mathrm{mg} . / 100 \mathrm{ml}$.). Ten days later, when the condition was responding to treatment, the $\alpha-\mathrm{NH}_{2} \mathrm{~N}$ level had risen to $5.0 \mathrm{mg} . / 100 \mathrm{ml}$. while the protein rad fallen to $100 \mathrm{mg} . / 100 \mathrm{ml}$. and the white

TABLE I

ALPHA-AMINO NITROGEN CONCENTRATIONS IN CEREBROSPINAL FLUID IN CONTROLS AND IN VARIOUS PATHOLOGICAL CONDITIONS

\begin{tabular}{|c|c|c|c|c|}
\hline \multirow[t]{2}{*}{ Condition } & \multirow[t]{2}{*}{ Source of Cerebrospinal Fluid } & \multirow[t]{2}{*}{ No. } & \multicolumn{2}{|c|}{$\alpha-\mathrm{NH}_{2} \mathrm{~N}(\mathrm{mg} . / 100 \mathrm{ml})}$. \\
\hline & & & Mean $\pm S . E$. & Range \\
\hline Controls (adult) & $\left\{\begin{array}{l}\text { Lumbar } \\
\text { Ventricular }\end{array}\right.$ & $\begin{array}{r}42 \\
8\end{array}$ & $\begin{array}{l}1.23 \pm 0.017 \\
1.13+0.046\end{array}$ & $0.96-1.47$ \\
\hline Controls (children under 5) & Lumbar & $\begin{array}{l}8 \\
8\end{array}$ & $1.09 \pm 0.061$ & $\begin{array}{l}0.91-1.36 \\
0.92-1.14\end{array}$ \\
\hline Meningitis, pyogenic & Lumbar & 6 & $3 \cdot 3 \pm 0.70$ & $1 \cdot 9-5 \cdot 4$ \\
\hline Meningitis, tuberculous & Lumbar & 1 & $4.9-$ & - \\
\hline & Lumbar & 1 & $1 \cdot 12-$ & - \\
\hline Gliomas & Lumbar & 1 & $3 \cdot 7^{1}-$ & \\
\hline Giomas & $\begin{array}{l}\text { Ventricular } \\
\text { Ventricular }\end{array}$ & $\begin{array}{l}6 \\
1\end{array}$ & $\begin{array}{l}1 \cdot 13 \pm 0.09 \\
2 \cdot 9^{2}\end{array}$ & $0.76-1.40$ \\
\hline Meningiomas & Lumbar & 2 & $1 \cdot 28-$ & $1 \cdot 27-1 \cdot 30$ \\
\hline Secondary carcinomas & Ventricular & 2 & $1.04-$ & \\
\hline Secondary carcinomas & Ventricular & 4 & $1.04 \pm 0.20$ & $0.69-1.50$ \\
\hline Acoustic neuroma & Ventricular & 1 & $1 \cdot 16-$ & - \\
\hline Cerebellar haemangioblastoma & Ventricular & 1 & $1.09-$ & - \\
\hline Multiple sclerosis & Lumbar & 33 & $1.01 \pm 0.085$ & $0.54-1.60$ \\
\hline Benign intracranial hypertension & Lumbar & 6 & $1.03 \pm 0.076$ & $0.85-1.36$ \\
\hline $\begin{array}{l}\text { 'Extensive subarachnoid spread } \\
\text { 2Fluid xanthochromic }\end{array}$ & & & & \\
\hline
\end{tabular}


cell count to $170 /$ c.mm. Chromatography (four samples) showed a generalized increase in aminoacids, including glutamine.

CEREBRAL TUMOURS In the majority of cases, the values for $\alpha-\mathrm{NH}_{2} \mathrm{~N}$ were within the control ranges for lumbar or ventricular cerebrospinal fluid. In three, the values were unusually low; in one $(0.76 \mathrm{mg}$./ $100 \mathrm{ml}$.) the tumour was a medulloblastoma, and in the other two $(0.69$ and $0.71 \mathrm{mg} . / 100 \mathrm{ml}$.) it was a secondary carcinoma. Gross elevations of cerebrospinal fluid $\alpha-\mathrm{NH}_{2} \mathrm{~N}$ were found in a case with xanthochromic fluid, and in a glioma with widespread subarachnoid dissemination.

MULTIPLE SCLEROSIS In 10 out of 33 cases $(30 \%)$, the concentration of $\alpha-\mathrm{NH}_{2} \mathrm{~N}$ was below the lower limit of the control range, and the mean concentration $(1.01 \mathrm{mg} . / 100 \mathrm{ml}$.) was significantly lower than in controls $(\mathrm{P}<0.01)$. The $\alpha-\mathrm{NH}_{2} \mathrm{~N}$ level was estimated in cerebrospinal fluid and plasma in six cases; in these the mean concentration in cerebrospinal fluid was $1 \cdot 1 \mathrm{mg} . / 100 \mathrm{ml}$. $(1 \cdot 12 \mathrm{mg}$./100 ml. cerebrospinal fluid water) and the mean concentration in plasma $4.2 \mathrm{mg} . / 100 \mathrm{ml}$. $(4.5 \mathrm{mg}$. $/ 100 \mathrm{ml}$. plasma water $R=0 \cdot 25$ ). Chromatography of three samples with subnormal $\alpha-\mathrm{NH}_{2} \mathrm{~N}$ suggested a decrease in all amino-acids.

MISCELLANEOUS CONDITIONS In five out of six cases of benign intracranial hypertension, the level of $\alpha-\mathrm{NH}_{2} \mathrm{~N}$ in lumbar cerebrospinal fluid was below the lower limit of the control range, and the difference between the mean value and that in controls was highly significant $(P<0 \cdot 001)$. Four cases of infected hydrocephalus in children had high concentrations similar to those found in meningitis in adults. In a case of spinal block due to a myxopapillary ependymoma, the $\alpha-\mathrm{NH}_{2} \mathrm{~N}$ level in lumbar cerebrospinal fluid was $4.3 \mathrm{mg}$. $/ 100 \mathrm{ml}$. In a case of haemangioma of the cord, the lumbar cerebrospinal fluid, which was xanthochromic, had an $\alpha-\mathrm{NH}_{2} \mathrm{~N}$ concentration of $3.0 \mathrm{mg} . / 100 \mathrm{ml}$. In the remainder of the conditions, including viral encephalitis (2), cerebrovascular insufficiency (4), motor neurone disease (1), and acute infective polyneuritis (1), values were normal.

\section{DISCUSSION}

Very few determinations of cerebrospinal fluid amino-acid nitrogen have been made by ninhydrin methods, which are the most specific available. The present results agree well with six normal values obtained by the standard gasometric ninhydrin technique (Christensen, Cooper, Johnson, and Lynch, 1947). The normal values in the older litera- ture, which are still widely quoted, were obtained by less specific methods (formol titration, nitrous acid, or Folin's colorimetric method) and are much higher than the present figures, ranging up to $4 \mathrm{mg}$. amino nitrogen per $100 \mathrm{ml}$., with a mean of about 2 (e.g., Weichmann and Dominicki, 1926; Lickint, 1929; Levinson, 1929; Katzenelbogen, 1935).

The correlation between $\alpha-\mathrm{NH}_{2} \mathrm{~N}$ concentrations in control samples of cerebrospinal fluid and plasma is of physiological interest. It has previously been shown that amino-acid levels in cerebrospinal fluid are raised when plasma amino-acids are pathologically increased (e.g., Lickint, 1929; Walshe, 1953; Müting, 1962) but it cannot be assumed that under all conditions the cerebrospinal fluid concentration of a given substance will be related to its concentration in the blood. Thus, the potassium concentration in cerebrospinal fluid is independent of that in plasma (Bradbury, Stubbs, Hughes, and Parker, 1963). The present findings emphasize the importance of estimating plasma amino-acids when altered amino-acid concentrations are found in the cerebrospinal fluid. In many studies this has not been done.

The physiological factors influencing the concentrations of amino-acids in cerebrospinal fluid are undoubtedly complex (Davson, 1956), and in pathological states so many more variables may be involved that a consistent relationship between a particular alteration in amino-acid levels and a given pathological state cannot be expected in every instance. There is, however, complete agreement that the total amino-acid concentration is raised in meningitis, both pyogenic and tuberculous (e.g., Weichmann and Dominicki, 1926; Lickint, 1929; Levinson, 1929; Katzenelbogen, 1935; Schönenberg, 1954; Schiavini and Nebbia, 1957). The rise is usually assumed to result from increased permeability of the blood-brain barrier, though proteolysis, tissue destruction, and decreased tissue uptake may also be involved. The present finding that the $\alpha-\mathrm{NH}_{2} \mathrm{~N}$ concentration in cerebrospinal fluid may be appreciably greater than that in the plasma suggests that increased permeability is not always the sole cause.

Lickint (1929) reported raised concentrations of cerebrospinal fluid amino nitrogen in cerebral tumours, whereas Logothetis and Bovis (1962) found that individual amino-acids were normal in five cases. In the present series, the level of $\alpha-\mathrm{NH}_{2} \mathrm{~N}$ was usually normal The occasional low values may have resulted from uptake of amino-acids by rapidly growing tumour tissue. High values were associated with neoplastic meningitis and with xanthochromia. In the xanthochromic fluid, proteolysis may have been an important factor in the rise. 
Walker et al. (1955) and Bauer and Boesche (1957) reported that cerebrospinal fluid amino-acids were normal in multiple sclerosis. The present work confirms the claims of Logothetis (1955) and Logothetis and Bovis (1962) that in some cases their concentrations are low. The plasma estimations did not suggest that this was the result of low plasma concentrations, a point of interest in view of the suggestion (Shatin, 1964) that malabsorption of amino-acids might be concerned in the pathogenesis of the disease. The permeability of the "bloodcerebrospinal fluid barrier' appears to be increased in multiple sclerosis (Haever, Tourtellotte, Richard, Gustafson, and Bryan, 1964) and this might be expected to increase amino-acid concentrations in the cerebrospinal fluid. No explanation of the reduction in amino-acids can be offered at the present stage. The concentration of $B_{12}$ in the cerebrospinal fluid of cases of multiple sclerosis is also unaccountably low (Basil, Brown, and Matthews, 1965). The low $\alpha-\mathrm{NH}_{2} \mathrm{~N}$ concentrations in cases of benign intracranial hypertension are similarly unexplained.

The results of this and other work may be summarized as follows. The $\alpha-\mathrm{NH}_{2} \mathrm{~N}$ concentration in the cerebrospinal fluid is normally about $30 \%$ of that in plasma, and is related to the plasma concentration. It is raised in meningitis (probably in all forms) and when the concentration in plasma is abnormally high. High values may also occur in spinal block and when blood has entered the cerebrospinal fluid. Low concentrations are normally found in children. They also occur in some cases of multiple sclerosis, of benign intracranial hypertension, and occasionally in association with cerebral tumours. Some of these changes are as yet quite unexplained, and merit further investigation.
We wish to thank the staff of the National Hospital, 을 Queen Square, for allowing us to study patients under $\vec{F}$ their care, and Professor J. N. Cumings for advice and $\stackrel{S}{9}$ criticism. We are grateful to Miss June Quick for tech-O nical assistance.

\section{REFERENCES}

Basil, W., Brown, J. K., and Matthews D. M. (1965). J. clin. Path., $18,317$.

Bauer, H., and Boesche, P. (1957). Klin. Wschr., 35, 511.

Bradbury, M. W. B., Stubbs, J., Hughes, I. E., and Parker, P. (1963). Clin. Sci., 25, 97.

Christensen, H. N., Cooper, P. F., Jr., Johnson, R. D., and Lynch, E. L. (1947). J. biol. Chem., 168, 191.

Davson, H. (1956). Physiology of the Ocular and Cerebrospinal Fluids, $\vec{\infty}$ p. 282. Churchill, London.

Eisenman, A. J., Mackenzie, L. B., and Peters, J. P. (1936). J. biol. Chem., 116, 33.

Haever, A. F., Tourtellotte, W. W., Richard, K. A., Gustafson, G. M. and Bryan, E. R. (1964). Neurology (Minneap.), 14, 345.

Katzenelbogen, S. (1935). The Cerebrospinal Fluid and its Relation to, the Blood, p. 174. Johns Hopkins Press, Baltimore.

Knauff, H. G. (1958). Nature (Lond.), 182, 937.

Levinson, A. (1929). Cerebrospinal Fluid in Health and in Disease, 3rd. ed., p. 123. Kimpton, London.

Lickint, F. (1929). Z. ges. Neurol. Psychiat., 120, 148

Logothetis, J. (1955). Neurology (Minneap.), 5, 767.

-, and Bovis, M. (1961). Wld Neurol., 2, 747.

-

Matthews, D. M. Muir, G. G., and Baron, D. N. (1964), J. clin Path., 17, 150.

Mestrezat, W. (1912). Le Liquide Céphalo-Rachidien, p. 131. Maloine, Paris.

Müting, D. (1962). Proc, Soc, exp, biol, (N.Y), 110, 620.

Schiavini, A. C., and Nebbia, L. (1957). Minerva pediat., 9, 1486.

Schönenberg, H. (1954). Z. Kinderheilk., 75, 301.

Shatin, R. (1964). Neurology (Minneap.), 14, 338.

Walker, B. S., Telles, N. C., and Pastore, E. J. (1955). Arch. Neurol. Psychiat. (Chic.), 73, 149.

Walshe, J. M. (1953). Quart. J. Med., 22, 483.

Weichmann, E., and Dominicki, M. (1926). Dtsch. Arch. klin. Med., 153,1 .

Westall, R. G. (1962). In Amino Acid Pools, edited by J. Holden, p. 202. Elsevier, London.

Williams, E. M., Donaldson, D., and Matthews D. M. (1965), Clin. chim. Acta. In the press. 